\title{
NOTE
}

\section{Squamous-cell carcinoma in rudd Scardinius erythrophthalmus}

\author{
Chutima Hanjavanit ${ }^{1}$, Maire F. Mulcahy ${ }^{1}$, Cuimin T. Doyle ${ }^{2}$ \\ ' Department of Zoology, University College, Cork, Ireland \\ ${ }^{2}$ Department of Pathology, University College, Cork, Ireland
}

ABSTRACT: Among 257 rudd Scardinius erythrophthalmus (L.) caught from Lough Aderry, a freshwater lake in East Cork, Ireland, 18 fish showed tumorous skin growths up to $1.4 \mathrm{~cm}$ in diameter The single or multiple tumours occurred most often at the base of the fins. The invasively growing neoplasms enclosed keratin-forming epithelial pearls and necrotic foci and were associated with extensive inflammation.

A total of 257 rudd Scardinius erythrophthalmus (L.) collected in May 1987 from Lough Aderry, East Cork, Ireland (Irish Grid Reference W 937 736) were investigated. Fish were examined both externally and internally for visible neoplasms. Of the fish caught $7 \%$ showed tumorous skin growths. Whole fish were fixed in Bouin's solution; the abdominal wall was opened to facilitate fixation of viscera. Tissues were embedded in paraffin wax, sections cut at 5 to $7 \mathrm{um}$ and stained with Ehrlich's haematoxylin and eosin (H\&E). Selected sections were also stained with Gram's stain and Periodic acid Schiff's reagent (PAS)

Fork-length and weight of fish ranged from 11.5 to $18.3 \mathrm{~cm}, 24.0$ to $82.7 \mathrm{~g}$ respectively, and ages as determined from scale reading varied from $2+$ to $3+$ yr.
Single or multiple external tumours were found in different regions of the body, but most frequently on the base of the caudal fin (Fig. 1). Tumours were raised, firm to touch, and deep red to brown in colour. Tumour size varied from $0.2 \times 0.2$ to $1.1 \times 1.4 \mathrm{~cm}$.

The epidermis of normal skin consists of a stratified squamous epithelium - the basal layer of cells having vertical orientation. Spherical mucous cells are interspersed throughout the epithelium and open onto the surface within the upper zone; club cells are numerous in the middle epidermal and the dermis is composed of fibrous connective tissues, scales and pigment cells

On microscopy, skin tumours were seen to be composed of sheets, cords and clusters of pleomorphic, squamous cells showing individual cell keratinisation and an infiltrating growth pattern (Fig. 2), - appearances characteristic of squamous-cell carcinoma. Invasion of the dermis and muscularis was associated with an intense inflammatory reaction. Individual neoplastic cells were large, round or elongated and slightly fusiform in shape with basophilic cytoplasm, pleomorphic nuclei, and prominent nucleoli. Mitotic figures
Fig. 1. Scardinius erythrophthalmus. Rudd showing tumours on the head and at the base of the caudal fin (arrows)

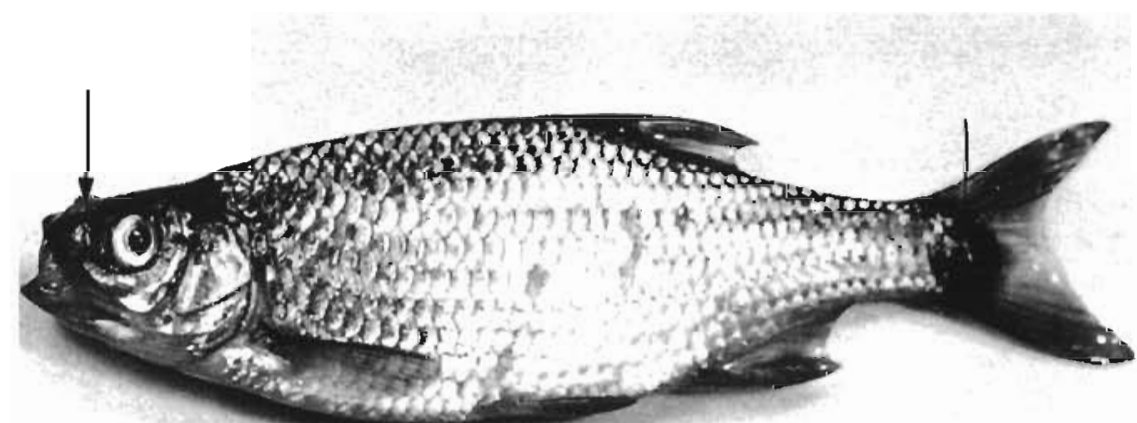

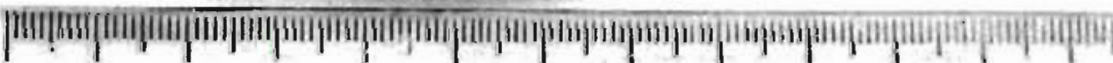

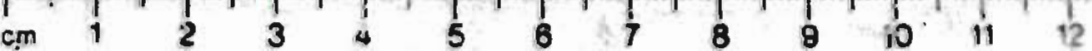




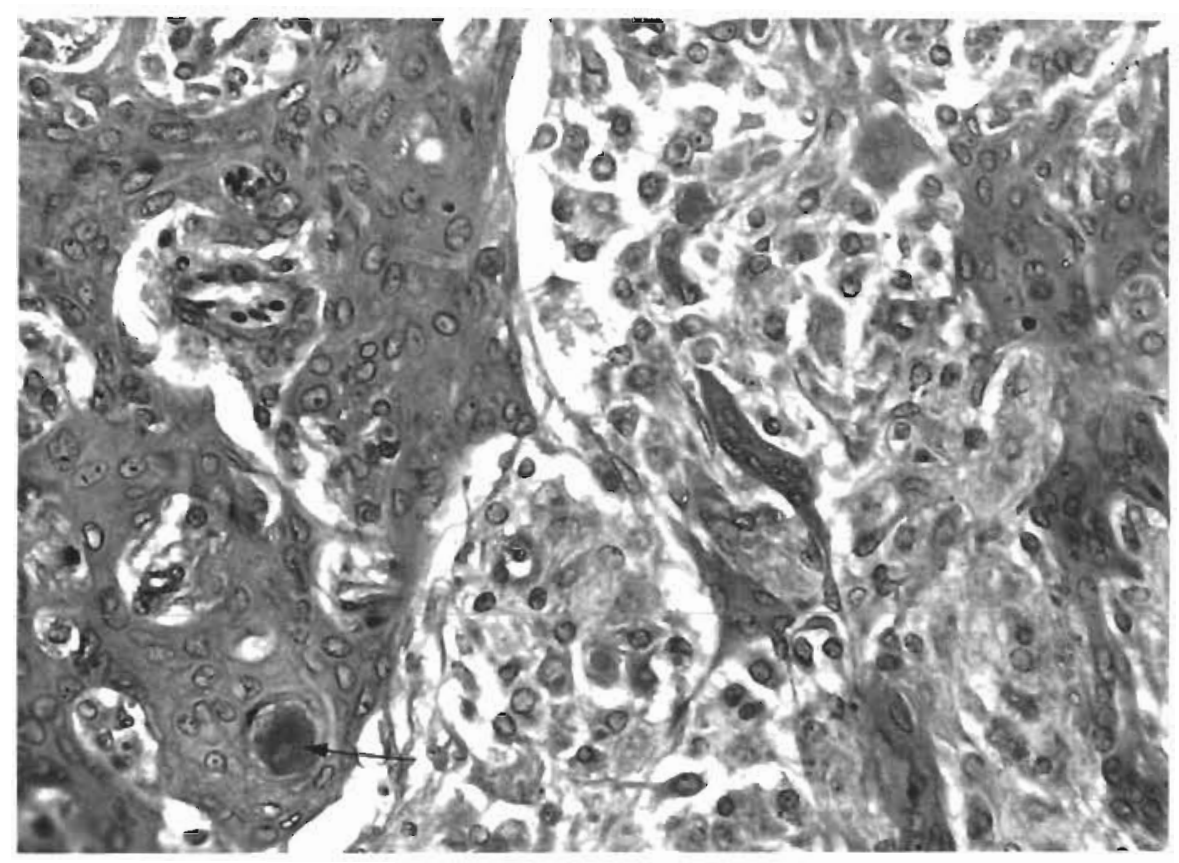

Fig. 2. Scardinius erythrophthalmus. Cross section of tumour skin showing infiltrating of squamous cell carcinoma and keratin (arrow) in dermis. H. \& $E_{1} \times 200$

were not abundant, but were occasionally seen. Numerous isolated mucous cells were scattered throughout the mass of tumour cells. There were also loci of necrosis and irregular deposits of neoplastic keratin within the tumour tissue. In some areas, tumour cells were arranged in cell-nests of stratified, squamous epithelium and with central, keratin-forming, characteristic 'epithelial pearls' Infiltration by inflammatory cells could be observed within the tumour mass. Small blood vessels were noted in the neoplasm and blood cells were localised in some tissue spaces. Infiltration of the muscularis by the tumour was seen in some cases. No bacterial infection was associated with any tumour tissues.

This is the first account of squamous-cell carcinoma in rudd. It is similar to those described below in having epithelial pearl formation, for example in gudgeon reported by Mawdesley-Thomas \& Bucke (1967), in gulf menhaden (Fournie et al. 1987) as well as in rainbow smelt (Herman 1988). However in rudd the mucous cells were scattered in the tumour mass whereas in gudgeon, clusters of mucous cells occurred within the malignant, epithelial cell-nests

Responsible Subject Editor: Professor N. Peters, Hamburg. F. R. Germany
Electron microscopic examination of these tumour tissues is in progress. The nature and aetiology of the neoplasms are being investigated experimentally and in the field.

Serial sections of these tissue have been deposited at the Registry of Tumors in Lower Animals (RTLA), Smithsonian Institute, Washington D.C., USA.

Acknowledgements. We are grateful to Dr J. C. Harshbarger (Registry of Tumors in Lower Anmmals, Smithsonian Institute, Washington D.C., USA) and Dr C. J. Dawe (Department of Pathology, Harvard Medical School, USA) for their comments on the histological findings. This study was supported by a grant from the Irish Cancer Society.

\section{LITERATURE CITED}

Fournie, J. W., Vogelbein, W. K., Overstreet, R. M. (1987). Squamous cell carcinoma in the gulf menhaden, Brevoortia patronus Goode. J. Fish Dis. 10: 133-136

Herman, R. L. (1988). Squamous cell carcinoma in rainbow smelt Osmerus mordax. Dis. aquat. Org. 5: 71-73

Mawdesley-Thomas, L. E., Bucke, D. (1967). Squamous cell carcinoma in a gudgeon (Cobjo gobio L.). Path. vet. 4: $484-489$

Manuscript first received: November 23, 1989

Revised version accepted: March 16, 1990 